\title{
HARDY-TYPE INEQUALITIES VIA CONVEXITY
}

\author{
Sten KAIJSER, Ludmila NiKolova, LARS-ERIK PERSSON AND ANNA Wedestig
}

\begin{abstract}
A recently discovered Hardy-Pólya type inequality described by a convex function is considered and further developed both in weighted and unweighted cases. Also some corresponding multidimensional and reversed inequalities are pointed out. In particular, some new multidimensional Hardy and Pólya-Knopp type inequalities and some new integral inequalities with general integral operators (without additional restrictions on the kernel) are derived.
\end{abstract}

Mathematics subject classification (2000): 26D10, 26 D15.

Key words and phrases: inequalities, Hardy's inequality, Pólya-Knopp's inequality, multidimensional Hardy type inequalities, Hardy type operators with kernel, weights, convex, concave.

\section{REFERENCES}

[1] P. R. Beesack And H. P. Heinig, Hardy's inequalities with indices less than 1, Proc. Amer. Math. Soc. 83 (1981), no. 3, 532-536.

[2] T. Carleman, Sur les fonctions quasi-analytiques, Comptes rendus du $\mathrm{V}^{e}$ Congres des Mathematiciens Scandinaves, Helsingfors, (1922), 181-196.

[3] A. ČIŽMEŠIJA AND J. E. PEČARIĆ, Some new generalisations of inequalities of Hardy and Levin-CochranLee, Bull. Austral. Math. Soc. 63 (1) (2001), 105-113.

[4] A. ČIŽMEŠIJA AND J. E. PEČARIĆ, On Bicheng-Debnath's generalization of Hardy's integral inequality, Int. J. Math. Math. Sci. 27 (4) (2001), 237-250.

[5] A. ČIŽMEŠIJA, J. E. PEČARIĆ AND L. E. PERSSON, On strengthened Hardy and Pólya-Knopp's inequalities, J. Approx. Theory 125 (2003), 74-84.

[6] G. H. HARDY, Notes on a theorem of Hilbert, Math. Z. 6 (1920), 314-317.

[7] G. H. HARDY, Notes on some points in the integral calculus (60), Messenger of Math. 54 (1925), $150-156$.

[8] G. H. Hardy, J. E. Littlewood And G. Pólya, Inequalities, $2^{\text {nd }}$ ed., Cambridge University Press, 1952 (1934).

[9] M. Johansson, L. E. Persson And A. Wedestig, Carleman's inequality: history, proofs and some new generalizations, J. Inequal. Pure Appl. Math., Vol 4, Issue 3, Article 53, (2003) (19 pages).

[10] S. KAIJSER, L. E. PERSSON AND A. ÖBERG, On Carleman and Knopp's inequalities, J. Approx. Theory 117 (2002), 140-151.

[11] K. KNOPP, Über reihen mit positivern gliedern, J. London Math. Soc. 3 (1928), 205-211.

[12] A. KufNer AND L. E. PERSSON, Weighted inequalities of Hardy type, World Scientific Publishing Co, Singapore / New Jersey / London / Hong Kong, 2003.

[13] A. KufNER AND L. E. PERSSON, The Hardy inequality - about its history and current status, Research report 6, Department of Mathematics, Luleå University of Technology, 2002.

[14] D. S. Mitrinović, J. E. PEČARIĆ AND A. M. FINK, Inequalities Involving Functions and Their Integrals and Derivatives, Kluwer Academic Publishers, 1991.

[15] C. P. Niculescu AND L. E. Persson, Convex Function - Basic Theory and Applications, Universitaria Press, 2003.

[16] D. V. ProkHOROV, Weighted Inequalities involving Riemann-Liouville and Hardy-Type Operators, $\mathrm{Ph}$. D. thesis, Department of Mathematics, Luleå University of Technology, 2003. 
[17] B. OPIC AND A. KufNer, Hardy-type inequalities, Pitman Research Notes in Mathematics 219, Longman Scientific \& Technical, Harlow, 1990.

[18] A. Wedestig, Weighted Inequalities of Hardy-Type and their Limiting Ineqalities, Ph. D. thesis, Department of Mathematics, Luleå University of Technology, 2003.

[19] B. YANG AND L. DEBNATH, Generalizations of Hardy's integral inequalities, Internat. J. Math. Sci. 22 (3) (1999), 535-542.

[20] B. YANG, Z. ZeNG AND L. DeBnath, On new generalizations of Hardy's integral inequality, J. Math. Anal. Appl. 217 (1998), 321-327. 